\title{
Effect of Various Herbicides on the Respiration of Soil Microorganisms ${ }^{1}$
}

\author{
L. C. Liu and H. R. Cibes-Viade ${ }^{2}$
}

\section{INTRODUCTION}

Weeds usually are suppressed in agricultural practice by the preemergence or postemergence application of herbicides. The toxic effect of herbicides often extends beyond the target species by affecting proximal vegetation and soil-borne organisms. It is of the utmost importance, therefore, to know how these compounds affect soil-borne organisms in a given medium. This research was conducted to determine the effect of various herbicides on the respiration of microorganisms contained in three typical Puerto Rican soils.

Fletcher (4) and Bollen (2) were, perhaps, the first investigators to review the effect of herbicides on soil microorganisms. Subsequently, Audus (1) gave a comprehensive account on this same topic. More recent and upto-date reviews were provided by Harris et al. (7) and Kaiser et al. (8). A great wealth of literature thus is presently available on this subject. Most of the studies, however, were conducted under temperate conditions. The only work of this nature accomplished locally was that of Dubey (3). He studied the effect of Picloram, Diuron, Ametryne and Prometryne on nitrification in three native soils. His investigation primarily was concerned with the effect of herbicides on nitrifying bacteria.

No information is available on the influence of these compounds on the respiration of soil microorganisms under Puerto Rican conditions. The everincreasing use of herbicides by Puerto Rican farmers has prompted us to obtain information not only on the persistence, penetration and other soil-herbicide relationships, but also on the interaction of various herbicides with soil microorganisms.

This paper deals with the effect on the gross respiration of soil microorganisms in general in three different Puerto Rican soil types of 2-chloro4-(ethylamino)-6-(isopropylamino)-s-triazine (Ametryne), 5-bromo-3-secbutyl-6-methyluracil (Bromacil), 3-(3,4-dichlorophenyl)-1-methoxy-1methylurea (Diuron), 1,1-dimethyl-3-( $\alpha, \alpha, \alpha$, trifluoro-m-tolyl) urea (Fluometuron, 3-(3,4-dichlorophenyl)-1-methoxy-1-methylurea (Linuron), 2,4 bis (isopropylamino)-6-(methylthio)-s-triazine (Prometryne), 3 tert-butyl-

1 Manuscript submitted to Editorial Board March 17, 1972.

2 Associate Plant Physiologist and Plant Physiologist, respectively, Agricultural Experiment Station, Mayagüez Campus, University of Puerto Rico, Río Piedras, P.R. 
5-chloro-6-methyluracil (Terbacil), $\alpha, \alpha, \alpha$, trifluoro-2,6-dipropyl-p-toluidine (Trifluralin) and amine salt of 2,4-dichlorophenoxyacetic acid (2,4-D Amine).

\section{MATERIALS AND METHODS}

A Warburg microrespirometer was used for the manometric measurement of respiration. Although this methodology is by no means ideal, it nevertheless has been utilized by several investigators $(5,6,9,10,11,12)$ with success. It has proven to be rapid and convenient for treatments involving different soil types, herbicide concentrations, etc., etc. The procedure described by Whiteside and Alexander (12) was followed in this investigation. Accordingly, $4.0 \mathrm{~g}$. air-dry samples each of Fraternidad and Coto clays and San Antón sandy loam were deposited in respirometers to

TABLE 1.-The physical and chemical properties of soils used in respiration study

\begin{tabular}{|c|c|c|c|c|c|c|c|c|c|c|}
\hline \multirow[b]{2}{*}{ Soil type } & \multirow[b]{2}{*}{$\mid \begin{array}{c}\text { Or- } \\
\text { ganic } \\
\text { matter }\end{array}$} & \multirow{2}{*}{$\begin{array}{l}\text { Cation } \\
\text { ex- } \\
\text { change } \\
\text { capac- } \\
\text { ity }\end{array}$} & \multicolumn{3}{|c|}{ Exchange bases } & \multirow{2}{*}{$\begin{array}{l}\text { Sol- } \\
\text { uble } \\
\text { phos- } \\
\text { phorus }\end{array}$} & \multirow[b]{2}{*}{ pH } & \multicolumn{3}{|c|}{ Texture } \\
\hline & & & $C_{a}$ & $\mathbf{M g}$ & $\mathbf{K}$ & & & $\begin{array}{c}\text { Sand } \\
(2- \\
0.05 \\
\mathrm{~mm} .)\end{array}$ & $\begin{array}{l}\text { Silt } \\
(0.05- \\
0.002 \\
\text { mm.) }\end{array}$ & $\begin{array}{c}\text { Clay } \\
(0.002 \\
\text { mm. or } \\
\text { less) }\end{array}$ \\
\hline & $\begin{array}{l}\text { Per- } \\
\text { cent }\end{array}$ & $\begin{array}{l}M \text { Meq. } \\
100 \mathrm{~g} .\end{array}$ & $\begin{array}{l}M \text { Meq. } \\
100 \mathrm{~g} .\end{array}$ & $\begin{array}{l}M \text { Meq. } \\
100 \mathrm{~g} .\end{array}$ & $\begin{array}{c}M 9 \mathrm{eq} . \mathrm{f} \\
100 \mathrm{~g}\end{array}$ & P.p.m. & & $\begin{array}{l}\text { Per- } \\
\text { cent }\end{array}$ & $\begin{array}{l}\text { Per- } \\
\text { cent }\end{array}$ & $\begin{array}{l}\text { Per- } \\
\text { cent }\end{array}$ \\
\hline Coto clay & 2.5 & 13 & 9.7 & 2.9 & 0.38 & 14 & 6.4 & 32 & 12 & 56 \\
\hline Fraternidad clay & 3.4 & 53 & 32.3 & 18.1 & 0.45 & 24 & 6.3 & 25 & 13 & 62 \\
\hline $\begin{array}{l}\text { San Antón sandy } \\
\text { loam }\end{array}$ & 2.9 & 22 & 25.1 & 6.9 & 2.64 & 55 & 7.8 & 66 & 15 & 19 \\
\hline
\end{tabular}

which 0.2 to $0.4 \mathrm{ml}$. of distilled water were added. The physical as well as the chemical properties of the above soils are shown in table 1 . The center well of the respirometers contained $0.2 \mathrm{ml}$. of a 20-percent $\mathrm{KOH}$ solution and a strip of filter paper. Technical grade Ametryne, Atrazine, Bromacil, Diuron, Fluometuron, Linuron, Prometryne and Terbacil were applied to the surface of the soil at the rate of $0,10,100$ and 250 p.p.m. in a 1-ml water suspension. Emulsifiable concentrates of Trifluralin and 2,4-D (amine salt) were similarly applied. The respirometers were then immersed and maintained in a water bath at $37^{\circ} \mathrm{C}$. After an equilibration period of 30 minutes the oxygen consumption was measured at 30-minute intervals for 8 hours. In a few instances, the reading interval was extended from 30 minutes to 1 hour. Microliters of oxygen consumed by the soil microorganisms were calculated with the aid of a predetermined flask constant $\left(\mathrm{KO}_{2}\right)$ values. The oxygen uptake by the soil samples was then expressed as a percent of the controls. All determinations were made in triplicate. 


\section{RESULTS}

The data presented in table 2 shows the effect of the various herbicide treatments on the oxygen uptake by the Coto clay soil. With only one exception (Terbacil) all herbicides at the lowest concentration ranked below the controls. In other words, they all inhibited oxygen consumption slightly. According to Fletcher (4), an herbicide concentration of 10 p.p.m., as used here, is comparable to a commercial application of 4 pounds per acre. At the 100 p.p.m.-concentration Trifluralin and 2,4-D further reduced the respiratory activity of microorganisms in this soil type. In this case only Fluometuron stimulated the uptake of oxygen. The inhibitory effect of Trifluralin, 2,4-D and Bromacil was still more intense at the 250 p.p.m.-concentration than at the lower ones.

In the Fraternidad clay soil none of the herbicides at the 10 p.p.m. series of concentrations showed much inhibitory effect on oxygen consumption. Instead, Diuron, Fluometuron, Ametryne and Atrazine increased somewhat the respiration rate of the microorganisms harbored in the soil. When the concentration of the various herbicides was raised from 10 to 100 p.p.m. there was a general tendency for a reduction in the oxygen uptake. Ametryne, Trifluralin and 2,4-D were the most influential in this respect. Ametryne applied at the above rate caused a drop from 103 to 93 while that induced by 2,4-D was about twice as much, that is, from 100 down to 82 . The situation under the highest herbicide concentrations remained more or less the same except with Trifluralin and 2,4-D. These two herbicides caused the most severe reduction in the oxygen uptake. As can be observed in table 2, Trifluralin had a consistent depressing effect as its concentration was steadily augmented in the soil. However, 2,4-D at 10 p.p.m. was equal to the control as regards the utilization of oxygen by the microorganisms but it had a drastic negative effect upon the oxygen uptake at the two succeeding doses.

There was practically no inhibitory effect of the various chemicals on the respiration of soil microorganisms in the San Antón sandy loam when they were applied at the rate of 10 p.p.m. On the contrary, all of them but Linuron increased the oxygen consumption. A remarkable increase in respiration was detected when the concentration of the herbicides was raised to 10 p.p.m. This was especially true of 2,4-D, Bromacil, Terbacil, Prometryne and Ametryne. Conversely, Trifluralin had a marked depressing effect. At 250 p.p.m. Fluometuron and Trifluralin greatly interfered with oxygen uptake while Linuron enhanced it over the previous two concentrations. The other herbicides did not vary much from their previous performances.

Of the three native soils included in this study, Coto clay was the most 
TABLE 2.-Effect of various herbicides on respiration of various soils, measured for 8 hours

\begin{tabular}{lcccc}
\hline \multirow{2}{*}{ Herbicide } & \multicolumn{4}{c}{ Oxygen uptake as percent of the control at herbicide concentration of- } \\
\cline { 2 - 5 } & Control 0 p.p.m.* & 10 p.p.m. & 100 p.p.m. & 250 p.p.m. \\
\hline \multicolumn{5}{c}{ Coto clay } \\
\hline Ametryne & 100 & 98 & 96 & 92 \\
Atrazine & 100 & 98 & 99 & 97 \\
Bromacil & 100 & 93 & 92 & 81 \\
Diuron & 100 & 94 & 99 & 95 \\
Fluometuron & 100 & 99 & 103 & 98 \\
Linuron & 100 & 96 & 95 & 93 \\
Prometryne & 100 & 96 & 97 & 96 \\
Terbacil & 100 & 101 & 98 & 95 \\
Trifluralin & 100 & 91 & 66 & 55 \\
2,4-D Amine & 100 & 93 & 78 & 58 \\
\hline
\end{tabular}

Fralernidad clay

\begin{tabular}{lrrrr}
\hline Ametryne & 100 & 103 & 93 & 93 \\
Atrazine & 100 & 102 & 98 & 107 \\
Bromacil & 100 & 98 & 96 & 97 \\
Diuron & 100 & 105 & 101 & 104 \\
Fluometuron & 100 & 106 & 105 & 103 \\
Linuron & 100 & 99 & 99 & 99 \\
Prometryne & 100 & 100 & 99 & 99 \\
Terbacil & 100 & 101 & 103 & 101 \\
Trifluralin & 100 & 96 & 93 & 87 \\
2,4-D Amine & 100 & 100 & 82 & 45 \\
\hline
\end{tabular}

San Anlón sandy loam

\begin{tabular}{lrrrr}
\hline Ametryne & 100 & 108 & 109 & 107 \\
Atrazine & 100 & 102 & 101 & 106 \\
Bromacil & 100 & 115 & 120 & 96 \\
Diuron & 100 & 100 & 97 & 92 \\
Fluometuron & 100 & 101 & 109 & 84 \\
Linuron & 100 & 96 & 98 & 114 \\
Prometryne & 100 & 109 & 110 & 98 \\
Terbacil & 100 & 101 & 111 & 105 \\
Trifluralin & 100 & 107 & 77 & 67 \\
2,4-D Amine & 100 & 109 & 124 & 108 \\
\hline
\end{tabular}

* The mean oxygen uptake for Coto clay is 54.1 microliter per hour; for Fraternidad clay, 98.0 microliter per hour, and for San Antón sandy loam 74.1 microliter per hour. 
severely affected in its oxygen uptake capacity by nearly all of the herbicide treatments to which it was submitted. Even at the lowest concentration 9 of the 10 herbicides decreased the respiration rate of this particular soil. Increasing the concentration worsened the outcome. San Antón was the least affected. Fraternidad soil was intermediate in this respect.

The differential response in oxygen uptake of the stated soils serves to underline the close relationship existing between the soil type and the degree of toxicity of an herbicide. Figures 1, 2, and 3 help illustrate this point.

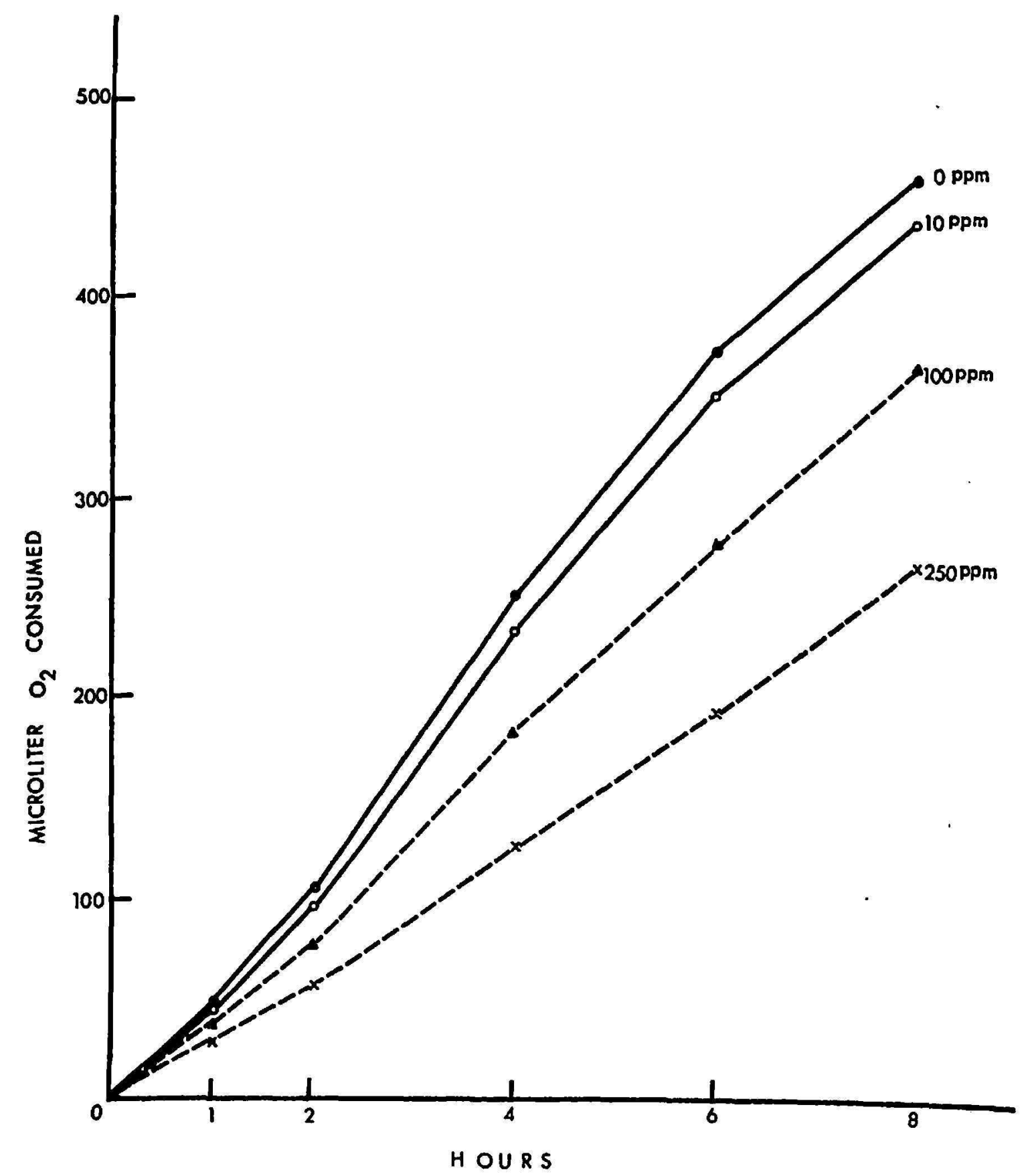

Fig. 1.-Oxygen consumption in Coto soil treated with varying concentrations of the amine salt of $2,4-\mathrm{D}$. 


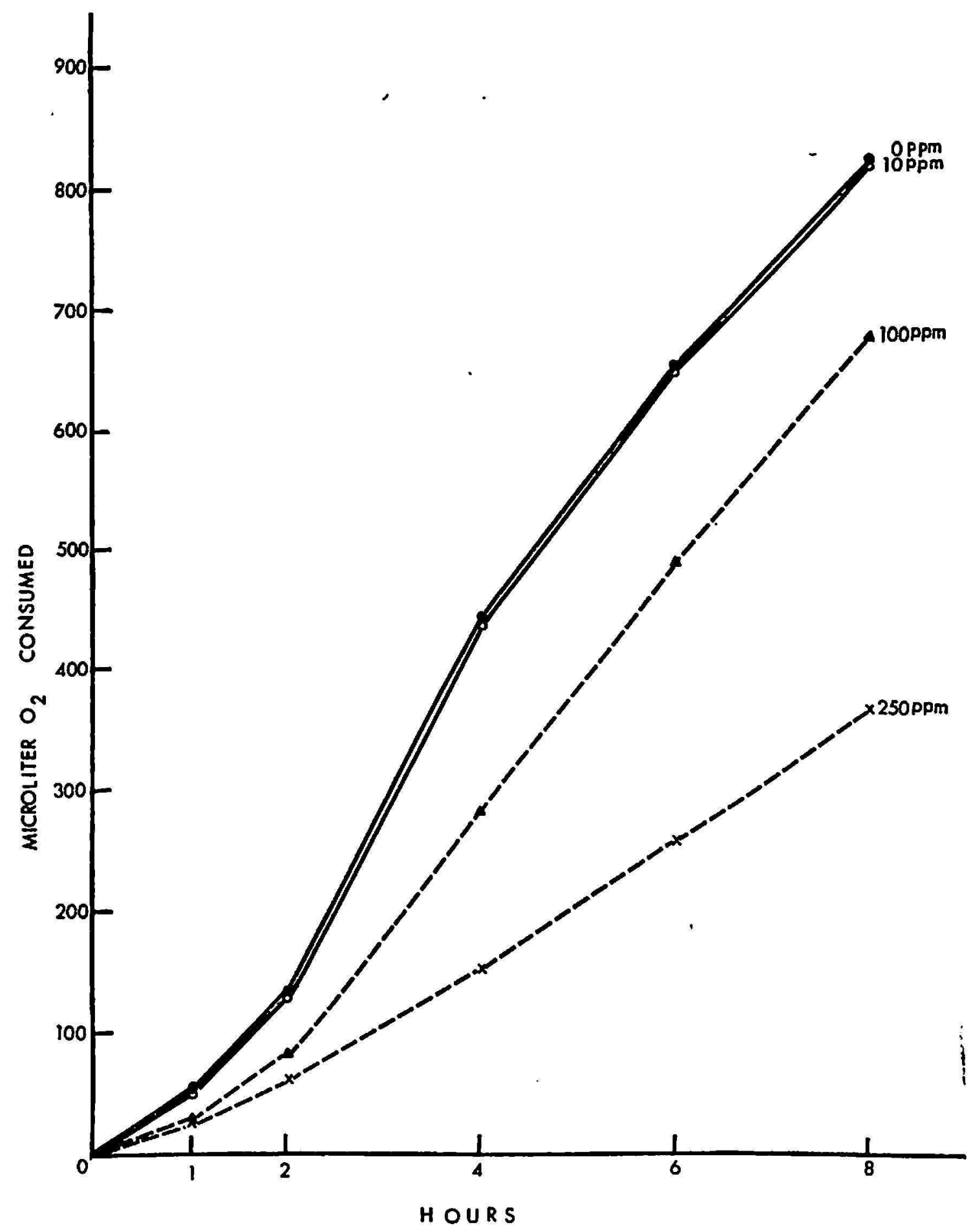

Fra. 2.-Oxygen consumption in Fraternidad soil treated with varying concentrations of the amine salt of 2,4-D.

Dubey (3) concluded that the effect of Picloram, Diuron, Ametryne and Prometryne on nitrification was greatly dependent on the nitrifying capacity of the soil. He found inhibition of nitrification by herbicides to be less in soils of high nitrifying capacity than in soils of low nitrifying capacity. No attempt was made to relate our findings with those obtained 
by Dubey. As stated before, our sole intention was to determine the gross effect of herbicides on the respiration of several soil types. Because nitrifying bacteria are particularly susceptible to herbicides, it was not possible for us to ascertain the detrimental effect of the aforementioned herbicides on nitrification. It is generally believed that any small contribution

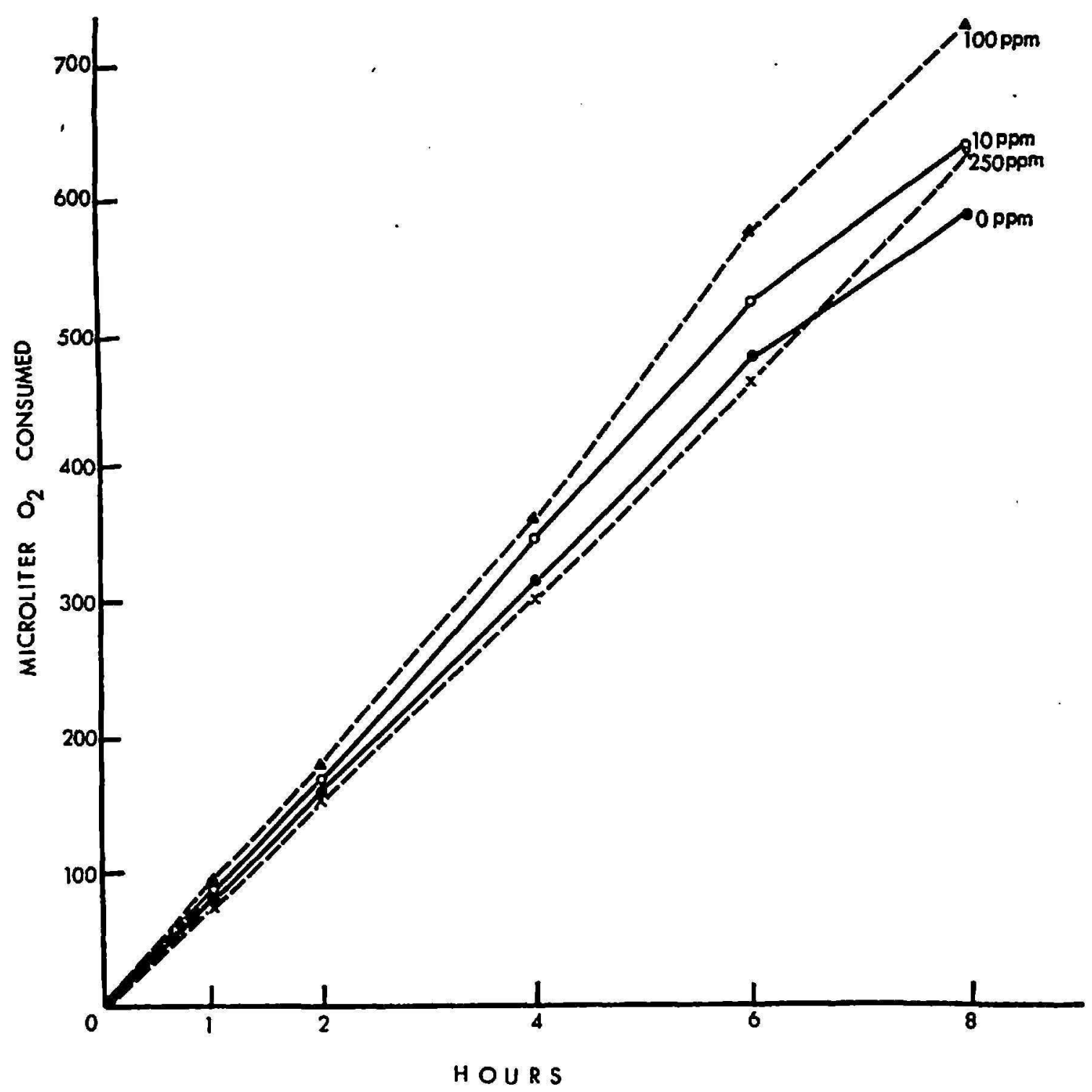

Fic. 3.-Oxygen consumption in San Antón soil treated with varying concentrations of the amine salt of 2,4-D.

by sensitive nitrifying bacteria to total respiration tends to be either masked or compensated by other biotic components of the soil.

\section{SUMMARY}

The effect of Ametryne, Atrazine, Bromacil, Diuron, Fluometuron, Linuron, Prometryne, Terbacil, Trifluralin, and 2,4-D on soil respiration was studied employing the Warburg apparatus. These compounds were 
used in various concentrations, i.e., $0,10,100$, and 250 p.p.m. The 10 compounds fell into three categories with regard to their effect on respiration of soil microorganisms:

1. A significant inhibitory effect on oxygen uptake was brought about by adding 2,4-D and Trifluralin to Coto and Fraternidad soils.

2. A weak inhibitory effect on oxygen uptake was noted for low concentrations of Bromacil, Diuron, Trifluralin, and 2,4-D, and for high concentrations of Ametryne, Bromacil, Linuron, and Diuron in soils.

3. A weak to moderate stimulatory effect on oxygen uptake was recorded with low concentrations of Ametryne, Diuron, Fluometuron, 2,4-D and for high concentrations of Atrazine, Linuron, and Terbacil in soils.

\section{RESUMEN}

Se estudiaron los efectos del Ametryne, Atrazine, Bromacil, Fluometuron, Linuron, Prometryne, Terbacil, Trifuralin y 2,4-D en la respiración de tres distintos suelos, utilizando un microrrespirómetro Warburg. Dichos compuestos se aplicaron a concentraciones varias; a saber, 0, 10, 100 y 250 p.p.m. Los 10 compuestos se clasificaron en las tres categorías siguientes, según sus efectos en la respiración de los microorganismos del suelo:

1. La aplicación de 2,4-D y Triafulin tuvo un efecto inhibitorio significativo respecto a la cantidad de oxígeno que consumieron la mayoria de los microorganismos del suelo.

2. La aplicación de Bromacil, Diuron, Fluometuron y 2,4-D a concentraciones bajas y de Ametryne, Bromacil, Linuron y Diuron a concentraciones altas tuvo un efecto inhibitorio leve respecto a la cantidad de oxígeno que consumieron los microorganismos del suelo.

3. La aplicación de Ametryne, Diuron, Fluometuron, 2,4-D a concentraciones bajas y Atrazine, Linuron y Terbacil a concentraciones altas tuvo un efecto estimulante entre leve y moderado respecto a la cantidad de oxigeno que consumieron los microorganismos del suelo.

\section{LITERATURE CITED}

1. Audus, L. J., Herbicide behavior in the soil. II. Interaction with soil microorganisms. The Physiology and Biochemistry of Herbicides, Academic Press, Inc., New York, N.Y., 1964.

2. Bollen, W. B., Interactions between pesticides and soil microorganisms, Ann. Rev. of Microbiol. 15: 69-92, 1961.

3. Dubey, H. D., Effect of Picloram, Diuron, Ametryne and Prometryne on nitrification, Proc. of Soil Sci. Soc. of America 33: 893-6, 1969.

4. Fletcher, W. W., The effect of herbicides on soil microorganisms, Herbicides and the Soil, Blackwell Scientific Publications, Oxford, England, pp. 20-62, 1960.

5. Gamble, S. J. R., Mayhew, C. J., and Chappell, W. E., Effect of herbicides on microorganisms, Soil Sci. 74: 347-50, 1952.

6. Hale, M. G., Hulcher, F. H., and Chappell, W. E., The effects of several herbicides on nitrification in a field soil, Weeds $5: 331-4,1957$.

7. Harris, C. I., Kaufman, D. D., Sheets, T. J., Nash, R. G., and Kearney, P. C., Behavior and fate of s-triazines in soils, Advances in Pest Control Research 8: 35-43, 1968. 
8. Kaiser, P., Pochon, J. J., and Cassini, R., Influence of triazine herbicides on soil microorganism, Residue Reviews 32: 211-33, 1970.

9. Magee, L. A. and Colmer, A. R., Some effect of 2,4-D upon Azotobacter as measured by respiration inhibition, Weeds $4: 124-30,1956$.

10. Magee, L. A. and Colmer, A. R., The action of some herbicides on the microorganisms. III. The effect of some herbicides on the respiration of Azotobacter, Applied Microbiology 3: 288-92, 1955.

11. Tu, C. M. and Bollen, W. B., Effect of Paraquat on microbial activities in soils, Weed Res. 8: 28-37, 1968.

12. Whiteside, J. E. and Alexander, M., Measurement of microbiological effects of herbicides, Weeds 8: 204-13, 1960. 